\title{
Formação do leitor: experiência intelectual e afetiva
}

\author{
Juracy Assmann Saraiva* \\ Ernani Mügge** \\ Tatiane Kaspari****
}

\section{Resumo}

O artigo valoriza a exploração de textos literários em ambiente escolar a partir do pressuposto de sua importância para a formação do sujeito. Objetiva discutir a dualidade que caracteriza a leitura de textos literários, situada entre o exercício intelectual e o engajamento corporal. Para isso, considera necessário inserir as práticas docentes no circuito dos estudos linguísticos e literários, que estabelecem elos entre linguagem e identidade. Sustentado em reflexão teórica, o artigo expõe um percurso metodológico de análise da obra literária, com potencial para concretizar a experiência estética por meio do processo de exploração linguística, que se congraça à subjetividade do imaginário de cada leitor, à natureza coletiva da linguagem e ao substrato social em que a literatura circula.

Palavras-chave: Literatura. Formação do leitor. Metodologia.

\section{Reflexões introdutórias}

No final da década de 1980, em seu ensaio "O direito à literatura", Antonio Candido assumiu uma defesa radical das manifestações artísticas. O filósofo

\footnotetext{
Doutora em Letras (PUCRS) e pós-doutora em Teoria Literária (Unicamp). É professora em cursos de graduação e de pós-graduação da Universidade Feevale. Como bolsista de produtividade do $\mathrm{CNPq}$, desenvolve pesquisas voltadas para o estudo da obra de Machado de Assis e para a metodologia do ensino da literatura. Em relação a Machado de Assis, publicou, entre outras obras, O circuito das memórias (Edusp, 2008); no âmbito da formação de leitores, é autora de Literatura na escola: propostas para o ensino fundamental (Artmed, 2006) e Palavras, brinquedos e brincadeiras: cultura oral na escola (Artmed, 2011), além de inúmeros artigos científicos. E-mail: jias@sinos.net

** Doutor em Letras (UFRGS) e pós-doutor em Cultura e Literatura (Universidade Feevale). Atua como professor no Programa de Pós-Graduação em Processos e Manifestações Culturais e no Mestrado Profissional em Letras, da Universidade Feevale, onde realiza pesquisas sobre a metodologia do ensino da literatura. Participou da organização da obra Texto literário: resposta ao desafio da formação de leitores (Oikos, 2018) e é autor de obras de ficção, sendo Pretérito (re)visitado (Oikos, 2017) sua publicação mais recente. E-mail: ernani@feevale.br

${ }^{* * *}$ Mestre em Processos e Manifestações Culturais (Universidade Feevale) e doutoranda desse mesmo programa. Desenvolve pesquisas sobre ensino e metodologia do ensino da literatura. Professora substituta no Instituto Federal de Educação, Ciência e Tecnologia do Rio Grande do Sul, IFRS, Campus Feliz. E-mail: tatianekaspari@ yahoo.com.br
}

Data de submissão: abr. 2019 - Data de aceite: jul. 2019 http://dx.doi.org/10.5335/rdes.v15i2.9260 
e crítico literário situou a discussão do acesso à literatura no campo da cidadania e afirmou que a privação do direito ao imaginário ocasiona a mutilação da personalidade do sujeito.

O debate proposto pelo pesquisador integrou um cenário de renovação política, com a promulgação da Constituição de 1988, que incidiu sobre o setor da educação. As decisões, então promulgadas, resultaram na Lei de Diretrizes e Bases - LDB -, de 1996, e orientaram a elaboração dos Parâmetros Nacionais Curriculares - PCNs -, de 1997 a 1999. Os documentos, porém, não asseguraram espaço para a inserção da literatura no ambiente escolar. Esse fato deflagrou reações de estudiosos como Leyla Perrone-Moisés (2006), que teceu considerações de ordem linguística, política e social para evidenciar que o menosprezo à literatura priva, sobretudo, as classes desfavorecidas do acesso à cultura escrita, especialmente no que tange aos textos canônicos, que fundam a identidade nacional.

As lacunas dos PCNs foram reconhecidas e ajustadas em outro documento legal, as "Orientações curriculares para o Ensino Médio”, de 2006, o qual restituiu à literatura seu estatuto de disciplina, sob a justificativa de assegurar "a autonomia e a especificidade que lhe são devidas" (BRASIL, 2006, p. 49). Pouco mais de uma década depois, todavia, a Base Nacional Comum Curricular - BNCC - reintegra a literatura à disciplina de
Língua Portuguesa, situando-a como um dos cinco campos de atuação social no Ensino Médio ${ }^{2}$. A iniciativa estimulou as históricas reflexões sobre o efetivo lugar do texto literário na escola, que situam, de um lado, a compreensão de que ele deve ser acomodado no mesmo nível de outros gêneros textuais e, por outro, a reivindicação de um espaço próprio.

(Des)orientados pelos documentos legais, instáveis quanto ao papel dos textos literários na formação dos estudantes, $\mathrm{e}$ pouco atentos à função ou à finalidade da literatura, explicitada por Antonio Candido, muitas vezes, professores ancoram suas práticas pedagógicas em informações extratextuais, como dados biográficos do autor e inserção em um período literário, ou em elementos linguísticos, desvinculados da construção de sentido textual. Essas atividades pouco contribuem para o desenvolvimento da proficiência leitora - haja vista os baixos índices em avaliações nacionais e internacionais - e não favorecem a inserção efetiva do aluno-leitor no processo de interpretação, a fim de que o texto reverbere em suas vivências.

Dessa forma, pela falta de valorização nos documentos que regulam a educação e pela inconsistência de abordagens pedagógicas habituais, a literatura é duplamente desprestigiada. Um posicionamento positivo frente ao trabalho com textos literários na escola emerge do cruzamento entre estudos linguísticos 
e literários, que estabelecem elos entre linguagem, processo de representação e identidade. A partir da consideração da centralidade da interação texto-leitor, os docentes podem redefinir percursos metodológicos de exploração de obras literárias em sala de aula, a fim de que o sentido se construa no entrecruzamento entre o plano da expressão linguística e da estrutura e o plano da percepção imagética de cada leitor.

\section{Texturas da linguagem verbal}

Na base da constituição do discurso, seja ele ficcional ou não, está a palavra. Isso explica os infindáveis embates filosóficos e linguísticos sobre a emblemática relação entre o verbo e a poesia, inaugurada por Platão e Aristóteles. Na longa trajetória de estudos, encontra-se, nas primeiras décadas do século XX, um grupo multidisciplinar de pensadores russos - 0 Círculo de Bakhtin, que busca uma visão crítica e ampliada dos fatos da linguagem.

Mikhail Bakhtin, que dá nome ao grupo, ocupa-se do processo de enunciação. Para ele, o texto recebe um acabamento e torna-se ideológico ${ }^{3}$ na "expressão individualizada da instância locutora" (BAKHTIN, 1997, p. 308), pois

[...] a língua penetra na vida através dos enunciados concretos que a realizam, e é também através dos enunciados concretos que a vida penetra na língua (BAKHTIN, 1997, p. 282).
Nessa concepção, a palavra não é, intrinsecamente, ideológica, mas sua inserção em uma situação comunicativa implica, necessariamente, um caráter ideológico. Para Bakhtin, o signo verbal existe em três dimensões:

Como palavra neutra da língua e que não pertence a ninguém; como palavra do outro pertencente aos outros e que preenche o discurso dos enunciados alheios; e, finalmente, como palavra minha, pois, na medida em que uso essa palavra numa determinada situação, com uma intenção discursiva, ela já impregnou de minha expressividade (BAKHTIN, 1997, p. 313).

Todo enunciado é, portanto, elaborado em vista do outro, mediante o emprego de palavras que já apresentam um "rastro ideológico" (PONZIO, 2008, p. 148), em que se entrecruzam opiniões, saberes, intenções. Consequentemente, a comunicação verbal pressupõe interlocução, pois, mesmo quando a resposta não ocorre de forma imediata ou não é verbalizada, a compreensão do enunciado infiltra-se na teia de vivências do sujeito, que se insere em um processo dialógico de contornos indefinidos, no qual a origem dos signos é sempre coletiva, social. Nesse cosmos heteroglóssico, o indivíduo revela-se como um "agitado balaio de vozes sociais" (FARACO, 2009, p. 84), estruturadas pela dupla dinâmica dos signos, que tanto refletem - apontam para uma realidade exterior, uma materialidade do mundo - quanto refratam - constroem diferentes interpretações, 
edificam verdades do horizonte apreciativo do ser humano, produzem formas de conceber a realidade (FARACO, 2009).

Em Bakhtin, o infindável questionamento que somente pode ser experimentado por meio da palavra - espaço habitado por um eu e por um outro - é a via pela qual se constitui a consciência de cada um. A exotopia provoca um olhar excedente do eu em relação ao outro, pois a posição exterior do eu permite-lhe o conhecimento de uma forma acabada do outro, a que ele não tem acesso:

O excedente da minha visão contém em germe a forma acabada do outro, cujo desabrochar requer que eu lhe complete o horizonte sem lhe tirar a originalidade. Devo identificar-me com o outro e ver o mundo através de seu sistema de valores, tal como ele o vê; devo colocar-me em seu lugar, e depois, de volta ao meu lugar, completar seu horizonte com tudo o que se descobre do lugar que ocupo, fora dele; devo emoldurá-lo, criar-lhe um ambiente que 0 acabe, mediante o excedente de minha visão, de meu saber, de meu desejo e de meu sentimento (BAKHTIN, 1997, p. 45).

Nessa compreensão, a experiência estética pressupõe a volta do sujeito a si mesmo, após o processo de identificação com o outro. Na diferença que estabelece em relação ao outro, completando o horizonte alheio sem descaracterizá-lo, o eu posiciona-se enquanto sujeito ${ }^{4}$.

As proposições teóricas de Bakhtin contribuem para pensar a linguagem como sistema de representação que possibilita a produção de sentidos e sustenta a cultura (HALL, 2016). Ao defender que "as coisas não significam: nós construímos sentido - conceitos e signos" (HALL, 2016, p. 13), Stuart Hall recusa tanto atribuir um sentido imanente ao mundo dos objetos, pessoas e eventos quanto considerar a onipotência do indivíduo em fixar o sentido da linguagem. Para o pesquisador, a produção de significação na cultura envolve um primeiro sistema representacional, configurado por mapas conceituais que elaboram formas de conceber e de organizar o mundo. Embora aparente ser particular a cada sujeito, esse sistema de conceitos possui uma dimensão coletiva, que possibilita sua comunicação por um segundo sistema de representação: a linguagem. Para Hall,

Isso é, de fato, o que significa quando dizemos que "pertencemos à mesma cultura". Porque nós interpretamos o mundo de maneiras grosseiramente similares, nós podemos construir uma cultura compartilhada de sentidos e, então, construir um mundo social em que habitamos juntos (HALL, 2016, p. 5).

Assim, os códigos, resultantes de convenções, "fixam as relações entre conceitos e signos", "estabilizam o sentido dentre diferentes linguagens e culturas" e equipam as pessoas de um grupo social de um "knowhow cultural, permitindo a elas que funcionem como sujeitos culturalmente competentes" (HALL, 2016, p. 9). Dentre as manifestações que dão forma à cultura, a literatura é tecida com 
o fio coletivo e dialógico das palavras, que emprestam sua forma inacabada à expressão de um mundo. $\mathrm{O}$ texto literário é interação com o outro desconhecido e, por isso mesmo, tem o leitor como pressuposto de sua existência.

\section{Arremates literários: 0 leitor}

Em 13 de abril de 1967, ao proferir uma palestra em comemoração ao sexagésimo aniversário de Gerhard Hess, reitor da Universidade de Constança, o professor Hans Robert Jauss não era capaz de vislumbrar os impactos de sua "provocação à teoria literária". Após criticar veementemente métodos de análise formalistas e marxistas, Jauss propôs compreender a historicidade literária como resultado da experiência dinâmica da recepção do texto, uma "partitura voltada para a ressonância sempre renovada da leitura, libertando o texto da matéria das palavras" (1994, p. 24). Sob esse prisma, não é pertinente fixar o sentido da obra literária no contexto de sua produção, tampouco abandoná-lo às vicissitudes de uma interpretação arbitrária fixada no presente.

Importa, no processo de análise textual, conciliar sincronia e diacronia, de forma que "a função eminentemente social da literatura" (JAUSS, 1994, p. 51) insurja nas relações de conciliação ou de confronto entre os horizontes da recep- ção do texto e de sua produção, ambos coletivos.

Para Jauss, a obra literária

[...] desperta a lembrança do já lido, enseja logo de início expectativas quanto a "meio e fim", conduz o leitor a determinada postura emocional e, com tudo isso, antecipa um horizonte geral da compreensão vinculado, ao qual se pode, então - e não antes disso colocar a questão acerca da subjetividade da interpretação e do gosto dos diversos leitores ou camadas de leitores (JAUSS, 1994, p. 27).

Jauss parte das reflexões de Hans Gadamer sobre o processo hermenêutico, sustentado na pergunta em relação à qual o texto é uma resposta, para buscar as razões da produção do objeto artístico em determinado momento histórico. A experiência estética, nesse processo de análise, não se confunde com a simples fruição, pois é definida pelo prazer que suscita. Ela "se realiza na oscilação entre a contemplação desinteressada e a participação experimentadora", pois "é um modo de experiência de si na capacidade de ser outro" (JAUSS, 1979a, p. 98).

O teórico alemão reconhece que o processo de leitura se efetiva nas arestas do efeito, "momento condicionado pelo texto" (JAUSS, 1979b, p. 73), e da recepção, "momento condicionado pelo destinatário, para a concretização do sentido como duplo horizonte" (JAUSS, 1979b, p. 73). Dessa forma, embora Jauss preconize o aspecto coletivo da recepção, não lhe afere a ideia de passividade. Em sua visão, 
É só de modo parcial que a necessidade estética é manipulável, pois a produção e a reprodução da arte, mesmo sob as condições da sociedade industrial, não consegue determinar a recepção: a recepção da arte não é apenas um consumo passivo, mas sim uma atividade estética, pendente da aprovação e da recusa (JAUSS, 1979b, p. 74).

A centralidade de um grupo de leitores ou do leitor na construção do sentido textual configura, pois, o eixo unificador da Estética da recepção, de Jauss, e da Teoria do efeito estético, de Wolfgang Iser. Ambos os pesquisadores insistem na ideia de que o propósito original de um texto literário é o de ser lido - e não, como supunham, pretensiosamente, grupos teóricos, o de ser submetido ao julgamento da crítica.

Para Iser, "a obra de arte dá satisfação ao receptor apenas quando ele participa da solução e não se limita a contemplar a solução já formulada" (1996, p. 95), porque o texto prefigura a recepção (1996, p. 7), isto é, apresenta-se como estrutura apelativa, lacunar:

Quase toda estrutura discernível em textos ficcionais mostra esse aspecto duplo: é ela estrutura verbal e estrutura afetiva ao mesmo tempo. $\mathrm{O}$ aspecto verbal dirige a reação e impede sua arbitrariedade; 0 aspecto afetivo é o cumprimento do que é pré-estruturado verbalmente pelo texto (ISER, 1996, p. 51-52).

O leitor, portanto, assume posição semelhante a um viajante, que leva consigo uma bagagem, seu repertório particular. Ao longo da viagem, ele acumula e combina paisagens, mas seu ponto de vista é móvel, errante, pois o trajeto - o texto - nunca está simultaneamente presente.

O sujeito, um ser de carne, que procede à leitura não se confunde, porém, com a noção de leitor implícito - o ser de papel:

[...] o leitor implícito não tem existência real; pois ele materializa o conjunto das orientações que um texto ficcional oferece, como condições de recepção, a seus leitores possíveis. Em consequência, o leitor implícito não se funda em um substrato empírico, mas sim na estrutura do texto. Se daí inferimos que os textos só adquirem sua realidade ao serem lidos, isso significa que as condições de atualização do texto se inscrevem na própria construção do texto, que permite constituir o sentido do texto na consciência receptiva do leitor. A concepção do leitor implícito designa então uma estrutura do texto que antecipa a presença do receptor (ISER,1996, p. 73).

Também Umberto Eco diferencia o receptor do texto do leitor implicado na urdidura textual. Para ele, o leitor-modelo

[...] constitui um conjunto de condições de êxito, textualmente estabelecidas, que devem ser satisfeitas para que um texto seja plenamente atualizado no seu conteúdo potencial (ECO, 1986, p. 45).

A concepção do leitor-modelo, no momento da produção textual, obedece a estratégias do autor ${ }^{5}$, que, paralelamente, pressupõe e institui a capacidade do leitor-modelo da obra. Assim, o texto, "mecanismo preguiçoso" (ECO, 1986, p. 36), prefigura seu destinatário como premissa de sua comunicabilidade e da potencialidade significativa, necessitando que ele preencha os não ditos ${ }^{6}$. Esses viabilizam 
a pluralidade de interpretações possíveis, que ecoam entre si sem causar exclusão.

Não obstante as aproximações possíveis, leitor modelo e leitor implícito não são conceitos equivalentes, sobretudo porque, para Iser, o sentido potencial de um texto não preexiste à leitura, ou seja, não é imanente à composição textual. $\mathrm{O}$ teórico atribui à obra - "ser constituído do texto na consciência do leitor" (ISER, 1996, p. 51) - a eventicidade que Bakhtin atribui à linguagem, pois o texto deve ser considerado "sob a premissa de ser comunicação" (ISER, 1996, p. 15) e somente é atualizado na leitura concreta:

A obra literária se realiza então na convergência do texto com o leitor; a obra tem forçosamente um caráter virtual, pois não pode ser reduzida à realidade do texto, nem às disposições caracterizadas do leitor (ISER, 1996, p. 50).

\section{Para Iser, a literatura}

[...] concede-nos ter coisas de dois modos: por tornar aquilo que é inacessível tanto presente quanto ausente. A presença acontece por meio da transformação encenada e a ausência pelo fato de que a transformação encenada é tão-só jogo (1999, p. 118).

A dinâmica da interação verbal no texto literário caracteriza-se, portanto, enquanto jogo, a que aderem os leitores:

Os autores jogam com os leitores e o texto é o campo do jogo. O próprio texto é o resultado de um ato intencional pelo qual um autor se refere e intervém em um mundo existente, mas, conquanto o ato seja intencional, visa a algo que ainda não é acessível à consciência (ISER, 1979, p. 107).
No jogo do texto literário, a dicotomia realidade $\mathrm{X}$ ficção é substituída pela tríade fictício $\mathrm{X}$ realidade $\mathrm{X}$ imaginário. $\mathrm{O}$ ato de fingir ${ }^{7}$ provoca

[...] a repetição da realidade no texto, atribuindo, por meio dessa repetição, uma configuração do imaginário, pela qual a realidade repetida se transforma em signo e o imaginário em efeito (Vorstellbarkeit) do que assim referido (ISER, 1979, p. 32).

Na leitura, os elementos são complementares, tendo em vista que o leitor lê o mundo artificial com as lentes do mundo sociopolítico e vice-versa, em um constante movimento de vai e vem ${ }^{8}$, em que são extrapoladas tanto a referência empírica quanto a configuração irrealizada do imaginário.

Embora o encerramento pleno do jogo textual seja inviável, Iser prevê três formas de o leitor concluí-lo a cada (re)leitura. A primeira possibilidade, a semântica, manifesta-se na necessidade de compreensão e premência de apropriação; a segunda, a experiência, configura-se na abertura do receptor ao não familiar, e a terceira, o prazer, corresponde ao "deleite derivado do exercício incomum de nossas faculdades" (ISER, 1979, p. 117). A conclusão do jogo não coincide, portanto, com o encerramento da experiência proporcionada pelo texto, que prossegue reverberando no imaginário.

Assim, o jogo textual não atende exclusivamente a finalidades lúdicas, mas 
satisfaz necessidades epistemológicas "presença com uma ausência esboçada pela negação" - e antropológicas - "concede conceber aquilo que nos é recusado" (ISER, 1979, p. 118). Para o teórico, há um propósito não verbalizado por detrás da concepção do "mundo irreal" do texto, permitindo a ele tornar-se um espelho do mundo real:

[...] ao considerar-se o mundo do texto apenas como se fosse real, o próprio mundo empírico se transforma num espelho, orientando o receptor para a concepção de algo que não existe e permitindo que esse inexistente seja visualizado como se fosse realidade (ISER, 1979, p. 74, grifos do autor).

A projeção de luz sobre o real faz com que as ficções desempenhem

[...] um papel importante tanto nas atividades do conhecimento, da ação e do comportamento quanto no estabelecimento de instituições, de sociedades e de visões de mundo (ISER, 2013, p. 43).

A literatura, assim, é uma forma paradigmática do processo de encenação entre fictício e imaginário, que vai construindo "visões de mundo". A encenação, que ocorre no texto ficcional, apresenta-se, portanto, como condição transcendental para os seres humanos, que, como desdobramento de si próprios, nunca poderão presentificar-se de modo pleno, mas tão somente configurar uma possibilidade limitada de si. Em consequência, há um autodesdobramento contínuo diante da permanente alter- nância de "composição e decomposição de mundos fabricados" (ISER, 1999, p. 77).

Situando-se a literatura no terreno das experiências do intangível e do desconhecido, é viável supor, como Ricoeur, uma afinidade entre "o segredo de onde a história emerge e o segredo ao qual a história retorna" (2012, p. 117). O potencial hermenêutico das narrativas, que articulam a aporética temporalidade, está na imbricação viva, no pano de fundo vivencial, na "estrutura pré-narrativa de experiência” (RICOEUR, 2012, p. 114) que dá origem às histórias e que permite uma experiência renovada de leitura, de acordo com a capacidade do leitor. Assim como o potencial significativo de uma narrativa ficcional é construído nos interstícios do texto, naquilo que não é explicitamente revelado, a história de uma vida é contada pelas narrativas silenciadas, e a potencialidade expressiva da linguagem é definida pelos sentidos ainda não presentificados.

Decorre dessas fendas uma perspectiva dos estudos teóricos recentes, que amplia as reflexões instauradas por Iser e por Jauss, direcionando-as à consideração do engajamento afetivo e corporal do leitor. Essa perspectiva desponta em estudos de Paul Zumthor, cuja teoria da performance "deixa formalmente íntegra a teoria alemã da recepção, mas lhe acrescenta uma dimensão que lhe modi- 
fica o alcance e o sentido" (ZUMTHOR, 2007, p. 52). O pesquisador defende que o processo de leitura desenrola-se paralelamente em duas dimensões: a da recepção, de caráter histórico e coletivo, e a da performance, categoria antropológica, que se refere à individualidade que o corpo do sujeito leitor imprime à leitura. Esta se relaciona

[...] por um lado, às condições de expressão, e da percepção, por outro, performance designa um ato de comunicação como tal; refere-se a um momento tomado como presente. A palavra significa a presença concreta de participantes nesse ato de maneira imedia$t a$. [...] a performance existe fora da duração. Ela atualiza virtualidades mais ou menos numerosas, sentidas com maior ou menor clareza. Ela as faz "passar ao ato", fora de toda consideração pelo tempo. Por isso mesmo, a performance é a única que realiza aquilo que os autores alemães, a propósito da recepção, chamam de "concretização" (ZUMTHOR, 2007, p. 50).

A noção de perfomance deriva dos estudos medievalistas realizados por Zumthor, nos quais a voz despontou como "qualidade de emanação do corpo" (2007, p. 27) e a poesia ${ }^{9}$, como atividade ritualística. Dessa forma, o texto artístico possui uma essência ressonante, que envolve a corporeidade do leitor: "o texto vibra; o leitor o estabiliza; integrando-o àquilo que é ele próprio. Então, é ele que vibra, de corpo e alma" (ZUMTHOR, 2007 , p. 53). Isso explica por que diferentes textos implicam posturas corporais distintas em sua leitura - ler uma notícia esportiva difere de ler um romance
-, visto que evidenciam o peso distinto que o corpo confere à experiência com o texto. A construção de sentido supõe que o leitor atravesse a resistência que a espessura das palavras impõe a ele, cuja "intervenção corporal" assume "a forma de uma operação vocal”. É

[...] nesse sentido que se diz, de maneira paradoxal, que se pensa sempre com o corpo: 0 discurso que alguém me faz sobre o mundo [...] constitui para mim um corpo-a-corpo com o mundo (ZUMTHOR, 2007, p. 77).

Zumthor ultrapassa a noção biológica de corpo, identificando-o como uma instância complexa, jamais plenamente presentificada, tornando possível uma aproximação com Bakhtin, quando este afirma a inviabilidade de o sujeito conceber uma imagem acabada de si. O corpo encarcera o indivíduo em sua condição humana e, no entanto, é a única via de manifestação e, de acordo com o medievalista, princípio de todo conhecimento, tendo em vista que os saberes de ordem sensorial constituem o fundo sobre o qual se ergue a racionalidade. Assim, embora não solucione o problema dos influxos orgânicos no processo de leitura, Zumthor defende que a experiência de leitura é, sempre, primordialmente, uma experiência de presença no mundo:

[...] a percepção é profundamente presença. Perceber lendo poesia é suscitar uma presença em mim, leitor. Mas nenhuma presença é plena, não há nunca coincidência entre eu e ela. Toda presença é precária, ameaçada (ZUMTHOR, 2007, p. 81). 
Dessa maneira, a via pela qual o corpo se presentifica mais plenamente é a voz, justamente porque ela "desaloja o homem do seu corpo" (ZUMTHOR, 2007, p. 84) e o lança em uma relação de alteridade. Sendo o "lugar simbólico por excelência” (ZUMTHOR, 2007, p. 83), "a voz é uma forma arquetipal, ligada para nós ao sentimento de sociabilidade" (ZUMTHOR, 2007, p. 86), pois

[...] escutar um outro é ouvir, no silêncio de si mesmo, sua voz que vem de outra parte. Essa voz, dirigindo-se a mim, exige de mim uma atenção que toma meu lugar, pelo tempo da escuta (ZUMTHOR, 2007, p. 84).

Por conseguinte, a performance assenta-se no caráter auditivo implicado na leitura das palavras de um texto artístico, as quais se enunciam "como a memória de alguma coisa que se apagou em nós" (ZUMTHOR, 2007, p. 86). Segundo o estudioso,

[...] a leitura do texto poético é a escuta de uma voz. O leitor, nessa e por essa escuta, refaz em corpo e em espírito o percurso traçado pela voz do poeta: do silêncio anterior até o objeto que lhe é dado, aqui, sobre a página (ZUMTHOR, 2007, p. 87).

Sob essa perspectiva, a primazia do sentido da visão é substituída pela percepção auditiva que, primeira sensação sensorial a despertar no feto, ao (re) conectar o ser humano a si próprio, integra-o à coletividade. Estaria nesse ponto uma das principais falhas do ensino de leitura na escola, tendo em vista a "espécie de surdez particular que nos inflige nossa educação literária" (ZUMTHOR, 2007, p. 69). Uma metodologia de leitura deve, pois, considerar a corporeidade que está presente nesse ato, em que a ressonância da voz é fundamental.

\section{Aprender literatura com literatura}

A apresentação de um percurso metodológico de análise textual tem o texto como início e fim, razão por que ela é precedida pelo movimento centrípeto que leva o leitor a perseguir o galope do cavalo "mais negro que a escuridão" (COLASANTI, 2005, p. 13), com que Marina Colasanti abre 23 histórias de um viajante. Nesse texto, o animal, conduzido pela Morte, transporta o leitor pelo universo simbólico de narrativas que parecem saídas de um tempo anterior ao do próprio homem; tempo de viajantes, de feiticeiras, de príncipes guerreiros e de animais falantes. A morte que vem buscar a personagem do conto inicial é presença substantiva nos contos, sendo ludibriada pelo próprio ato de contar histórias.

Especialmente significativa, a narrativa "O riso acima da porta", que também integra a obra de Colasanti, apresenta a história de um homem que é decapitado por um crime que não cometera. Sua cabeça é fixada acima da porta da casa onde havia morado e, sob a ação do sol, deforma-se, dando a impressão 
de que exibe um sorriso. O carrasco, ao ver a caveira, surpreende-se com $o$ riso, que interpreta como uma mostra de sua eficiência profissional, uma vez que a vítima nem percebera a execução, sentindo, talvez, apenas "um arrepio de cócegas no pescoço" (COLASANTI, 2005, p. 172). Anos após, realizando o lúgubre ofício de maneira automatizada, o carrasco sente orgulho de seu trabalho e dedica-se a afiar o machado. Também a esposa da vítima percebe o sorriso estampado no rosto preso acima da porta, ao acompanhar o voo de uma ave contra a qual praguejava por ter defecado nas roupas estendidas no varal. A imagem da face morta desperta-lhe contrição, uma vez que, para ela, o marido demonstra estar mais feliz do que fora em vida. A consciência acerca da amargura cotidiana que caracterizara sua vida conjugal lança luz sobre as ações da esposa, que se abre para as "delicadezas até então ignoradas” (COLASANTI, 2005, p. 173). Em contraste com a mãe, a filha da vítima sente satisfação ao visualizar o sorriso na face ressecada. Lateja na garota a certeza de que o pai, finalmente, reconhecera o valor de ter uma filha doce e valente, não mais lamentando a ausência de um filho varão. Finalmente, quando as primeiras nuvens se formam no céu, o homem que cometera o crime que causou a injusta execução vê a cabeça sorridente. A constatação da alegria da vítima junta-se ao remorso e convence o assassino a se entregar à justiça. Então, desaba uma tempestade, que derruba a cabeça do batente da porta, desfazendo-a em um estalar de ossos.

No interior dessa narrativa, a cabeça do homem morto serve como texto a ser interpretado pelas personagens, que partem de uma compreensão consensual, baseada em elementos referenciais - 0 sorriso da vítima, manifesto na expressão facial -, para construir sentidos que derivam de suas próprias idiossincrasias. A compreensão do riso-texto lança luz sobre diferentes âmbitos da vida cotidiana das personagens - ofício, relações conjugais e filiais - e, ao deflagrar reflexões de natureza moral, orienta mudanças nas ações e nos sentimentos.

Diante da multiplicidade de pontos de vista, instaurados pelas diferentes personagens, o leitor é convidado a integrar-se ao circuito interpretativo. Uma das formas mais aguçadas de sedução textual está na audibilidade e na visibilidade, as quais emergem com força na narrativa de Marina Colasanti. Nela, os apelos sensoriais conjugam ambiente e personagens, de forma que a informação inicial - de que as chuvas tardavam a cair - instaura um fenômeno climático que acompanha o desenrolar das ações. Ambas, ações das personagens e situação meteorológica, culminam no desfecho do conto, em que a cabeça do morto pende ao vento, até "desabar, num estalar de 
ossos desfeitos, que a trovoada encobriu" (COLASANTI, 2005, p. 165).

No enunciado final do texto, a referência ao fenômeno climático extremo e, particularmente, a aliteração de /s/ e de sons plosivos, como /t/, /d/ e /k/ sustentam uma ambientação sonora dramática, tensional. Ela remete ao estado emocional do assassino, que decide se entregar à morte, mas também fecha o ciclo diegético, em que a existência do riso-texto está condicionada ao desfecho natural, ou seja, as chuvas só desabam quando a justiça se efetiva na morte do verdadeiro criminoso.

A sonoridade evocada pelo estrato verbal da narrativa confere um colorido sonoro ao texto, mobilizando, inconscientemente, reações sensoriais. O principal procedimento de escrita aural, porém, parece estar na proposição textual de uma voz narrativa arquetípica, identificada com um nômade, alheio à temporalidade e à espacialidade. $\mathrm{O}$ contador de histórias, representado em 23 histórias de um viajante, não implora por acolhida, porque tem consciência do valor de sua moeda de troca - as narrativas. Paradoxalmente, sua força é, também, sua maior fragilidade. É personagem de papel, que só existe se alguém "real" lhe emprestar a voz. Mas, por ser de papel, sua existência transcende à do corpo agenciado e permite que desfile pelo tempo e por um número infindável de territórios.
Nas narrativas de Colasanti, ou o leitor sacode a poeira da realidade dos pés e acolhe o forasteiro contador de histórias em sua própria corporeidade ou o texto se cala, intraduzível. Ou o leitor se posta ao redor da fogueira do tempo em que os mitos são elaborados, como necessidade antropológica de compreensão do mundo, ou continuará refém do presente ruidoso, surdo ao "barulho de fundo existencial" (ZUMTHOR, 2007, p. 76).

Essa escolha radical, pela ficção, na produção de Colasanti, mobiliza o imaginário e o diálogo com o "outro-estrangeiro", que habita o "eu", e transcende a informação veiculada nos textos. Esses se concentram em pequenos feitos cotidianos ou em episódios prosaicos de uma vida e se identificam com os contos infantis ou com o passado mítico. O fundo poético das narrativas de Colasanti, intimamente aural, registra a sonoridade das palavras e causa uma impressão, se não de encantamento, de um desconcerto perante as histórias que calam no leitor, exatamente porque evocam memórias inexatas, incompatíveis com a realidade atual. Com a delicadeza do imaginário infantil, o rosto da morte se desenha no e pelo mundo ficcional, restituindo à vida humana a eternidade que nunca pertenceu a ela.

Assim, essas narrativas reafirmam que, imergindo em si, o sujeito encontra a coletividade de que faz parte, antes mesmo de ter nascido. Como afirma 
Zumthor, "a voz poética nos declara [...] que, aconteça o que acontecer, não estamos sozinhos" (2007, p. 86). É nesse ponto que a prática escolar relacionada à Literatura também deve tocar, sob pena de anular a própria essência. Afinal, a linguagem - objeto central das aulas de língua e de literatura - é o sistema representacional que confere um "acabamento humano" ao mundo real.

\section{O texto, frente e verso: proposta de percurso metodológico}

Esse objeto de estranha potência, a literatura, engendra resistência de alunos e professores à sua inserção escolar: aqueles, resistem pela inabilidade em construir sentidos - ou, pelo menos, em acessar o sentido pretendido pelo docente - e estes, pela falta de orientações claras e eficientes para a abordagem do texto estético em sala de aula.

O caráter singular do trabalho com a linguagem e mesmo a particularidade do contexto de recepção das obras artísticas inviabilizam a fixação de um modelo de leitura, de análise e de interpretação universalmente válido. Ainda assim, é possível apontar itinerários pedagógicos, desde que as atividades de análise considerem os elementos linguísticos e estruturais que emergem como mais relevantes para a construção de sentidos do texto em particular.
Como adverte Marisa Lajolo, "técnicas milagrosas para convívio harmonioso com o texto não existem, e as que assim se proclamam são mistificadoras, pois estabelecem uma harmonia só aparente, mantendo intacto - quando já instalado - o desencontro entre leitor e texto" (2002, p. 14). Sob essa perspectiva, o esforço em promover uma imagem aprazível e atraente acerca da literatura se esfacela diante da tensão entre texto e leitor, vivenciada pela resistência que as palavras oferecem à construção do sentido, ao demandarem um exercício intelectual. Em outras palavras, ao propor somente atividades lúdicas e ao restringir a seleção de textos àqueles que correspondam ao horizonte de expectativas dos alunos, o professor deixa de capacitar os discentes para a leitura crítica e aprofundada, que determina a proficiência leitora. Em certa medida, a abordagem fundamentalmente lúdica do texto literário é o extremo oposto da leitura automatizada do cânone, e é, igualmente, pouco produtiva para que o aluno ascenda os degraus da compreensão leitora de textos com maior complexidade.

Diante desse contexto, um caminho de articulação entre a experiência estética e o exercício intelectual, instigados pelas obras literárias, pode ser encontrado na proposição de roteiros de leitura (SARAIVA; MÜGGE, 2006). As etapas metodológicas previstas nesse percurso 
de análise e interpretação remetem aos estudos de Hans Robert Jauss (1983), que, no início da década de 1980, propôs a tripartição do ato de leitura: a primeira, de percepção, seguida da interpretação retrospectiva e da leitura histórica da recepção.

Apropriando-se dos estudos de Jauss, Saraiva (2000) conjuga a proposição desse teórico às reflexões de Iser acerca do leitor, para propor um percurso metodológico de exploração do texto literário na Educação Básica. A pesquisadora traduz as três etapas de Jauss como "entender, interpretar e aplicar" (2006, p. 48) e distingue três momentos para a leitura de textos literários, que são a preparação para a recepção do texto, a leitura compreensiva e interpretativa e a transferência e aplicação de leitura. Saraiva adverte que a segmentação dos processos envolvidos na leitura configura um "procedimento operatório", pois é na intersecção de todos os aspectos que se constrói um "processo hermenêutico único" (SARAIVA, 2006, p. 48).

Os partícipes da pesquisa, de que resulta este artigo, justificam a previsão de uma etapa prévia à leitura do texto pela necessidade de estimular os alunos, especialmente importante em turmas que apresentam resistência à leitura. É uma estratégia breve que deve estabelecer um elo entre o leitor e o texto a ser lido.

Esse contato prévio com o texto deve evitar, tanto quanto possível, condicionar a leitura ou oferecer uma interpretação, baseada em características do autor e de sua produção. A finalidade dessa etapa é abrir os ouvidos e os olhos do leitor, para que a imaginação entre em cena. Por exemplo, no caso da narrativa de Marina Colasanti, "O riso acima da porta", uma possibilidade seria explorar a significação do título, perguntando, aos alunos, o que poderia motivar o registro de algo risível exposto na entrada principal de uma casa.

A leitura do texto, que segue a esse momento inicial, pode ser realizada das mais diversas formas - oral ou silenciosa, individual ou coletiva -, conforme as estratégias definidas pelo professor, mas a exposição do texto por meio da voz deve ser privilegiada. Em se tratando de obras mais extensas, o docente estipula prazo para a leitura e solicita que ela seja feita fora do horário escolar. Todavia, nestes casos em que não é possível a leitura do texto em voz alta, é importante que sejam previstos momentos, ao longo da exploração textual, em que os traços vocais sejam evidenciados e estimulem a inserção da corporeidade dos leitores.

O segundo passo metodológico, a Leitura compreensiva e interpretativa, é composto por três etapas, que perfazem a leitura compreensiva, a analítica e a interpretativa. A primeira delas corresponde à abertura para a constelação de significados possíveis de uma obra. Ao final da leitura do texto - e, por vezes, 
exclusivamente após várias releituras -, o aluno deve estar apto a responder à seguinte pergunta: $\mathrm{O}$ que o texto diz?

A configuração do segundo momento, a leitura analítica, "é determinada pela especificidade da composição do texto a ser explorado" e se destina a conduzir o leitor em sua busca pelos "elementos que o texto disponibiliza para sua interpretação" (SARAIVA, 2006, p. 49). Nessa etapa, as atividades propostas envolvem aspectos estruturais do gênero em questão, questões linguísticas relevantes para a instauração de sentido, uso das modalidades de discurso e os efeitos sobre o receptor; as relações intertextuais; a natureza metaficcional do texto etc. Ao final da etapa, o leitor deve saber responder à seguinte proposição: Como o texto diz o que diz?.

Bastante próxima e, por vezes, diluída no passo anterior, está a leitura interpretativa, que "resulta da sobreposição de leituras" (SARAIVA, 2006, p. 50), em que as leituras prévias se tornam horizonte das posteriores. O horizonte retrospectivo de interpretação recupera as progressivas camadas de sentido e as projeta na vivência do leitor. Ao responder à pergunta quais são os sentidos do texto?, “[...] o leitor correlaciona-o à sua situação pessoal, de modo que a significação textual passa a impregnar-se de sentido, isto é, da experiência humana, cultural e historicamente situada" (SARAIVA, 2006, p. 50).
Para exemplificar a aplicabilidade da leitura compreensiva e interpretativa na narrativa de Colasanti, considera-se que a compreensão do texto está ligada à apreensão do esquema básico das ações, que pode ser identificado espontaneamente na leitura ou em uma atividade que exija a seleção das principais ações e sua disposição segundo a relação de causa e consequência. Nesse ponto, já se inicia a leitura analítica, que deve suplantar o nível da identificação e evidenciar, por exemplo, que, em "O riso acima da porta”, o paralelismo sonoro e das ações representadas - as personagens que passam em frente à cabeça do executado - instauram uma tensão narrativa, importante para a construção da unidade textual e para a captação do leitor. Ao mesmo tempo, ele reproduz o jogo paralelístico presente em canções infantis ou nas manifestações artísticas populares, o que pode causar a sensação de familiaridade no leitor, já estando configurada aí uma leitura interpretativa.

A última etapa metodológica do percurso organizado por Saraiva corresponde à Transferência e aplicação do texto, que transcende os limites desse para enlaçá-lo a elementos do contexto estético-histórico-cultural. Nesse momento, a produção textual é elemento obrigatório e deve ser submetida à reescrita. Quanto mais interdisciplinares forem as atividades propostas, maiores as possibilidades de resposta para a pergunta: Que diálogo 
há entre o texto e o contexto estético-histórico-cultural atual e o do momento de sua produção?. Assim, a recuperação da biografia do autor, de sua produção literária e de sua participação no cenário sociocultural do período de produção encontra espaço nessa etapa de trabalho com o texto e possibilita o confronto entre os efeitos da obra no leitor contemporâneo e os registros acerca da recepção no contexto de escrita. Para essa etapa, as narrativas de Colasanti descortinam um sem-número de opções, que devem atender aos propósitos pedagógicos do professor. Uma via profícua de abordagem seria o estabelecimento de relações com As mil e uma noites ou com os cordéis nordestinos, na medida em que as manifestações se aproximam pela configuração de uma voz narrativa envolvente e que lança raízes no tempo. Outra possibilidade é o registro, pelos alunos, de histórias próprias, contadas pelos avós ou recolhidas da cultura popular ou, ainda, o estudo dos escritos de viajantes de diferentes épocas e de sua biografia ${ }^{10}$.

Para finalizar, além das condições nomeadas nas sessões anteriores, Mügge (2011) recorda que o êxito dessa proposta de leitura do texto literário está associado à organização de enunciados claros nas questões voltadas aos alunos; à organização das atividades, preferencialmente, de acordo com a sequência textual; a alternância dos tipos de exer- cício - questões dissertativas, objetivas, tabelas etc. -; a apresentação estética do material entregue ao discente. A atenção a esses aspectos demonstra comprometimento e respeito do professor ao aluno e facilita a adesão à proposta de trabalho. Porém, para que alcance eficácia, esse percurso de leitura de textos literários não pode ser esporádico.

Constância é palavra-chave para o êxito das práticas de formação de leitores. Assim como a literatura é ritualização da linguagem, a leitura em sala de aula também deve ser ritualizada. Para isso, os textos literários devem ser considerados, nos documentos ligados à educação, pela particularidade da experiência, concomitantemente cognitiva e afetiva, que propiciam ao leitor e que os diferencia no universo das manifestações verbais. Seja pelo estímulo ao pleno desenvolvimento psíquico, ao atender à necessidade vital de fantasia; seja pela revelação da malha cultural e social em que se insere o sujeito, a literatura justifica sua inserção no ambiente escolar e demanda práticas pedagógicas que inscrevam professores e alunos no circuito de leitores críticos, capazes de discutir, por intermédio do mundo representado, suas vivências cotidianas. 


\section{Reader Formation: Intellectual and Affective Experience}

\section{Abstract}

The article values the exploration of literary texts in a school environment based on the assumption of their importance for the formation of the individual. It aims to discuss the duality that characterizes the reading of literary texts, located between intellectual exercise and corporal engagement. In order to accomplish this, however, it is necessary to include teaching practices in the circuit of linguistic and literary studies, which establish links between language and identity. Following theoretical reflections the article exposes a methodological course of analysis of the literary work, with the potential to concretize the aesthetic experience through the process of linguistic exploration, which harmonizes the subjectivity of each reader's imaginary to the collective nature of language and to the social substratum in which literature circulates.

Keywords: Literature; Reader Formation; Methodology

\section{Notas}

1 O ensaio é publicado, posteriormente, na obra Vários escritos, que consta da lista de referências desse artigo.

2 No Ensino Fundamental, são quatro os campos de atuação social. Para a afirmação relativa ao Ensino Médio, considera-se a terceira versão da BNCC, disponível em: <http://basenacionalcomum.mec.gov.br/wp-content/uploads/2018/04/ BNCC_EnsinoMedio_embaixa_site.pdf $>$. Acesso em: 27 jun. 2018.

3 A utilização do termo ideologia é sempre espinhosa, por se relacionarem a ele diferentes acepções, oriundas de seu emprego em dis- cursos diversos ao longo do tempo. Segundo Augusto Ponzio, o sentido a ele atribuído recebe diferentes nuances nos estudos bakhtinianos, mas, de maneira geral, caracteriza-se como "[...] a expressão das relações histórico-materiais dos homens, mas 'expressão' não significa somente interpretação ou representação, também significa organização, regularização dessas relações" (PONZIO, 2008, p. 113).

4 Essa noção de sujeito é problematizada por possuir "um caráter excessivamente consciente" (NARDI, 2007, p. 46) e por estar apartada de relações com a psicanálise (FARACO, 2009), mas opera um movimento importante de reintegração do sujeito aos estudos linguísticos.

5 Eco apresenta uma distinção também para a categoria de autor. Para ele, o autor empírico corresponde ao sujeito real, cuja inserção no texto se dá por meio da instituição de um autor-modelo, que constitui uma estratégia discursiva e cujo compromisso se restringe às circunstâncias da enunciação.

6 “'Não-dito' significa não manifestado em superfície, a nível de expressão", o que "requer movimentos cooperativos, conscientes e ativos da parte do leitor" (ECO, 1986, p. 36).

7 O fictício organiza o jogo do texto por meio da seleção - mobilização e disposição textual de elementos do campo de referências extratextuais -, da combinação - transgressão de campos de referência intratextual - e da autoevidenciação - instituição do "como se", que, ao mesmo tempo em que representa um mundo, assinala a intraduzibilidade verbal dessa realidade (ISER, 1999, p. 70).

8 O movimento de leitura é descrito, por Paul Ricoeur (2012), em um modelo em espiral, em que a meditação passa pelo mesmo ponto diversas vezes, mas sempre em outra altitude.

9 Zumthor esclarece que toma o termo "poesia" em sentido amplo, de forma a englobar as manifestações literárias.

10 Neste último caso, podem ser citadas as obras contemporâneas Diário do clima, de Sônia Bridi, que conta a viagem da jornalista e de seu marido por 14 países, a fim de avaliar os impactos da ação humana no meio ambiente; $\mathrm{e}$ Cem dias entre céu e mar, de Almir Klink, que conta as aventuras de uma viagem marítima de mais de 6500 quilômetros. Nesses casos, a intertextualidade pode ser facilmente estabelecida com conhecimentos de Biologia, História e Geografia, por exemplo. 


\section{Referências}

BAKHTIN, Mikhail. Estética da criação verbal. São Paulo: Martins Fontes, 1997.

BENJAMIN, Walter. O narrador - Considerações sobre a obra de Nikolai Leskov. In:

Magia e técnica, arte e política: ensaios sobre literatura e história da cultura. 8 ed. revista. São Paulo: Brasiliense, 2012. p. 213-240.

BRASIL. Orientações curriculares para o Ensino Médio: Linguagens e suas tecnologias, 2006. Disponível em: <http://portal.mec.gov. br/seb/arquivos/pdf/book_volume_01_internet.pdf>. Acesso em: 08 jun. 2018.

CANDIDO, Antonio. $\mathrm{O}$ direito à Literatura. In.: CANDIDO, Antônio. Vários escritos. São Paulo: Duas cidades, 1995. p. 169-191.

COLASANTI, Marina. 23 histórias de um viajante. São Paulo: Global 2005.

ECO, Umberto. Lector in fabula. Tradução: CANCIAN, Attílio. São Paulo: Perspectiva, 1986.

FARACO, Carlos Alberto. Criação ideológica e dialogismo. In: . Linguagem \& diálogo: as ideias linguísticas do Círculo de Bakhtin. São Paulo: Parábola Editorial, 2009. p. 45-97.

HALL, Stuart. The Work of Representation. In: _ Cultura e Representação. Tradução de William Oliveira e Daniel Miranda. Rio de Janeiro: PUC-Rio; Apicuri, 2016. p. 1-62.

ISER, Wolfgang. Atos de fingir. In.: . $O$ fictício e o imaginário: Perspectivas de uma Antropologia Literária. 2. Ed. Rio de Janeiro: Eduerj, 2013. p. 31-56.

HALL, Stuart. O fictício e o imaginário. In: ROCHA, João Cezar de Castro. Teoria da ficção: indagações à obra de Wolfgang Iser. Rio de Janeiro: Eduerj, 1999. p. 65-77.

HALL, Stuart. $O$ ato da leitura: Uma teoria do efeito estético. v. 1. São Paulo: Editora 34, 1996.
HALL, Stuart. O jogo do texto. In: LIMA, Luís Costa (Org.). A Literatura e o leitor: textos de estética da recepção. Rio de Janeiro: Paz e Terra, 1979. p. 105-118.

JAUSS, Hans Robert. A história da literatura como provocação à teoria literária. Trad. Sérgio Tellaroli. São Paulo: Ática, 1994.

JAUSS, Hans Robert. O texto poético na mudança de horizonte da leitura. In: LIMA, Luiz Costa (org.). Teoria da literatura em suas fontes. $2^{\mathrm{a}}$ Ed. Rio de Janeiro: F. Alves, 1983. p. 305-358.

JAUSS, Hans Robert. O prazer estético e as experiências fundamentais da Poiesis, Aisthesis e Katharsis. In: LIMA, Luiz Costa (org.). A Literatura e o leitor: textos de estética da recepção. Rio de Janeiro: Paz e Terra, 1979a. p. 85-104.

JAUSS, Hans Robert. A Estética da Recepção: colocações gerais. In: LIMA, Luiz Costa (org.). A Literatura e o leitor: textos de estética da recepção. Rio de Janeiro: Paz e Terra, 1979b, p. 67-84.

LAJOLO, Marisa. Do mundo da leitura para a leitura do mundo. 6 ed. São Paulo: Ática, 2002.

BRASIL. MEC. Base Nacional Comum Curricular - $3^{\text {a }}$ versão. 2018. Disponível em: < http://basenacionalcomum.mec.gov. br/wp-content/uploads/2018/04/BNCC_EnsinoMedio_embaixa_site.pdf $>$. Acesso em: 27 jun. 2018.

MÜGGE, Ernani. Ensino médio e educação literária: propostas de formação do leitor. 2011. Tese (Doutorado em Letras) - Programa de Pós-Graduação em Letras, Universidade Federal do Rio Grande do Sul - Ufrgs, Porto Alegre.

NARDI, Fabiele Stockmans de. Um olhar discursivo sobre língua, cultura e identidade: Reflexões sobre o livro didático para o ensino de espanhol como língua estrangeira. 2007. Tese (Doutorado em Letras). Porto Alegre: Ufrgs. Disponível em: https://www.ufrgs.br/ ppgletras/defesas/2007/FabieleStockmansNardi.pdf>. Acesso em 12 dez. 2016. 
PERRONE-MOISÉS, Leyla (2006). Literatura para todos. In: Literatura e Sociedade. São Paulo: USP/ FFLCH/ DTLLC, no 9. p. 16-29. Disponível em: <https://edisciplinas. usp.br/pluginfile.php/17073/mod_resource/ content/1/Perrone-Moises\%2C\%20Leyla.\%20 Literatura\%20para\%20todos.pdf $>$. Acesso em: 08 fev. 2018.

PONZIO, Augusto. Signo e ideologia. In: . A revolução bakhtiniana: o pensamento de Bakhtin e a ideologia contemporânea. São Paulo: Contexto, 2008. p. 109-159.

RICOEUR, Paul. Tempo e narrativa. A tripla mímesis. In: Tempo e narrativa. A intriga e a narrativa histórica. São Paulo: Editora WMF Martins Fontes, 2012. p. 93 - 156.

SARAIVA, Juracy Assmann; MÜGGE, Ernani. Literatura na escola: propostas para o ensino fundamental. Porto Alegre: Artmed, 2006.

SARAIVA, Juracy Assmann. A indissociabilidade entre língua e literatura no ensino fundamental: uma metodologia integradora. In: SARAIVA, Juracy Assmann; MÜGGE, Ernani. Literatura na escola: propostas para o ensino fundamental. Porto Alegre: Artmed, 2006.

ZUMTHOR, Paul. Performance, Recepção, Leitura, 2. ed. São Paulo: Cosac Naify, 2007. 